International Journal of Life Sciences
Available online at www.sciencescholar.us
Vol. 5 No. 1, April 2021, pages: 1-13
e-ISSN: 2550-6986, p-ISSN: $2550-6994$
https://doi.org/10.29332/ijls.v5n1.1120

\title{
International Environmental Law and Its Legal Implication
}

\author{
(C) CrossMark \\ Antonio Vázquez Pérez a, Dolores Rosalía Cedeño Meza b , Ángel Fabián Erazo Chávez c, Mayra \\ Alejandra Moreira Macías ${ }^{\mathrm{d}}$, Lenin Rodrigo Guerrero Cedeño ${ }^{\mathrm{e}}$
}

Manuscript submitted: 27 February 2021, Manuscript revised: 18 March 2021, Accepted for publication: 9 April 2021

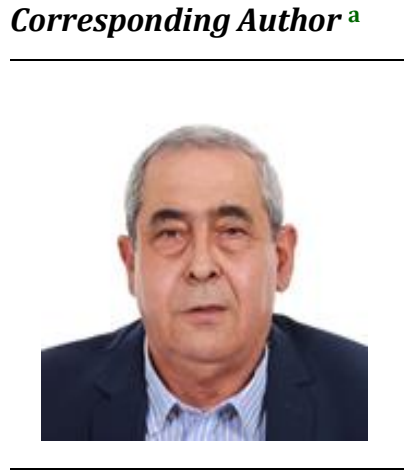

Keywords

environment; constitutionalism; environmental law; irreversible impacts; precautionary principle;

\begin{abstract}
The objective of the work is to offer a reflection of the place that international environmental law occupies as and its influence so that, at the internal level of the countries, binding norms are adopted, in the interest of environmental protection. The relevance of environmental law consists of the need to achieve regulatory solutions, to the pressure to which environmental systems are subjected. It is necessary to regulate the behaviors that imply consequences on the environment, to be managed through the law as legal norms that ensure respect for nature and achieve sustainable development. The analysis is carried out in a temporary context of 30 years, since the branch of law emerged on an international scale, with the constitutional movement in some Latin American countries and especially in Ecuador. For this, the comparative legal method was applied and the Desk Research method of investigation was used for the bibliographic review. The influence of international norms for the current development of Ecuadorian environmental law is exposed.
\end{abstract}

International Journal of Life Sciences (C) 2021. This is an open access article under the CC BY-NC-ND license (https://creativecommons.org/licenses/by-nc-nd/4.0/).

\section{Contents}

Abstract

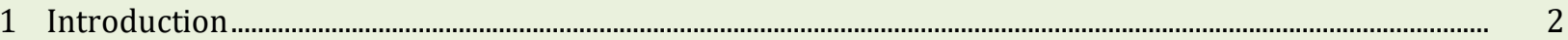

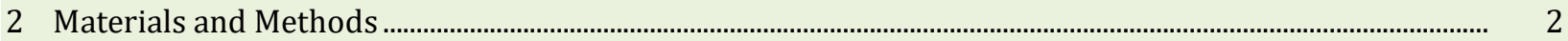

3 Results and Discussions ..................................................................................................................................................

${ }^{a}$ Departamento de Industrial de la Facultad de Ciencias Matemática, Física y Química de la Universidad Técnica de Manabí, Portoviejo, Ecuador

${ }^{\text {b }}$ Abogada de los juzgados y tribunales de la República del Ecuador. Libre ejercicio de la profesión, Manabí, Ecuador

c Fiscalía General del Estado, Portoviejo, Manabí Ecuador

${ }^{\text {d }}$ Abogada de los juzgados y tribunales de la República del Ecuador, Portoviejo, Manabí, Ecuador

e Abogado de los juzgados y tribunales de la República del Ecuador, Portoviejo, Manabí, Ecuador 


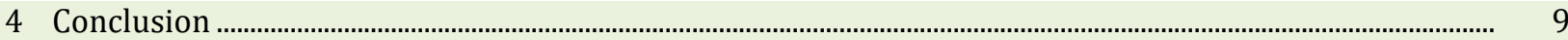

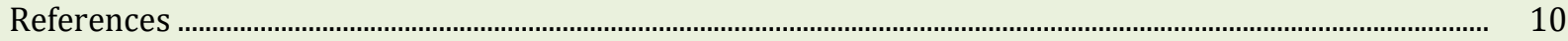

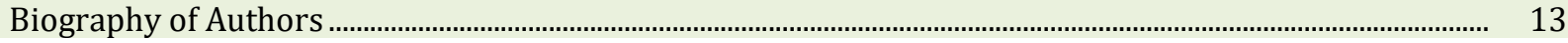

\section{Introduction}

The new environmental problems that arise require specific legal treatment. The interests of the international protection of the environment and its effects at the level of the national sovereignty of the countries, for the treatment of the effects and adaptation to climate change and the protection of the ozone layer, requires a differentiated legal treatment, but that Respond to international agreements and treaties (Lagos, 2005; Ribadeneira, 2016; Vastag et al., 1996; Cooter, 1994).

International environmental law is in constant systemic transformation. Its development is based on a constant process of structural adaptation to the dynamics of social actors at the international level and for this it incorporates new elements of analysis into its theoretical structure (Giles, 2003; Sesma, Díaz and Müller, 2004). During the second half of the 20th century, voices began to rise at the international level, which advocated bringing to the legal discussion the need to strengthen international environmental law. The rapid increase in the number of international cooperation agencies and agencies for environmental treatment contributed to promoting spaces within the United Nations for the emergence and development of this new branch of law.

In the context of the development of international environmental law, discussion in the academic field has gained space on the problem of binding and non-binding regulation (Baxter, 1980; Jaquenod, 1991; Thürer, 2000; Pastor, 2002). What has been analyzed above allows us to assume the low level of application of international legal regulations on environmental law, especially for Latin American countries, where there is a tendency to make the application of environmental regulations more flexible under the criterion of benefiting economic development.

At the international level, the situation is not very different, as there are no suitable jurisdictional mechanisms to require compliance with the environmental agreements assumed. In this way, it can be seen that international environmental law has a tint of especially political and programmatic law, so it can be said that regulations on the environment at the international level are configured as non-binding norms that promote a certain regulatory relaxation. The objective of the work is to promote the analysis and discussion of the place that international environmental law occupies as a non-binding regulatory platform and its influence so that, at the internal level of the countries, more and more regulations are adopted with a binding nature in the interest of environmental protection.

\section{Materials and Methods}

The comparative legal method was applied to establish the influence of international environmental law, as a source for the establishment of national norms and regulations with a binding nature, which manage to increase the effectiveness of this type of law. In the discussion of the results, some reasoned criteria are reflected, which allow raising the debate about international environmental law as a type of flexible law, which needs to be strengthened in the interest of safeguarding the legal effectiveness of this right.

All this allowed to establish as a research hypothesis that: international environmental law arose and is maintained as a set of non-binding regulations, which implies a wide flexibility in compliance with environmental regulations that threatens their effective compliance, therefore It requires the incorporation of binding regulations and standards that increase the legal effectiveness of this right.

The research is based on a descriptive bibliographic review work, which made it possible to characterize international environmental law, as an integration of regulations and norms that offer an important level of flexibility for their compliance as non-binding regulations, which is not conducive to achieve a higher level of legal effectiveness for this right.

For this, a bibliographic review of books, articles, manuals, laws, regulations, conventions, agreements and other documents from primary sources was carried out, which offered information in the interest of delving 
into the subject studied, for which theresearch method was applied. DeshResearch (Hofman and Sutherland, 2018), which involved the use of existing data, which were collected, analyzed and summarized to increase the overall effectiveness of the research, produce critical analyzes and reach precise conclusions on the subject studied (Hernández, Fernández and Baptista, 2010; Millard et al., 2001; Law et al., 2002).

\section{Results and Discussions}

\section{The precautionary principle in international environmental law}

The precautionary principle set out in the Rio Declaration (UN, 1992a), has a lot to do with the non-binding nature of international environmental law. The purpose of the declaration was to protect the environment. It is emphasized that the states must broadly apply the precautionary criterion according to their capacities. Where there is danger of serious or irreversible damage, the lack of absolute scientific certainty should not be used as a reason to delay the adoption of cost-effective measures to prevent environmental degradation.

It is pointed out that it should be borne in mind, no matter how commonplace it may seem, we live increasingly submerged in a risky society, in the face of which the various disciplines of knowledge and knowledge cannot be oblivious to it. This demand or contemporary reality represents a permanent challenge from its own conceptual framework to the institutions and branches that concern it, including by the way the issue of the principles of international environmental law.

The precautionary principle must be applied in today's highly technical society, especially in decisionmaking processes in conditions of ignorance and uncertainty. For some situations, the irreversibility of the catastrophic damage does not allow a sensible reference to a repair or compensation. Especially precaution makes sense when science does not offer an answer or there is conflict between different experts (Riechman and Tickner, 2002).

A group of non-governmental organizations in the field of biotechnology has proposed an equation to efficiently postulate the principle of Caution: Scientific uncertainty + Suspicion of damage = Precautionary action (Artigas, 2001; Covaci et al., 2011; Scanlon, 2007). But everything is not rosy, because in the legal debate criteria are used that try to minimize the importance and validity of the precautionary principle of international environmental law. It is even pointed out that it is practically a dialectical trap and is sometimes used as a weapon to support a policy in defense of an impossible security, based on society's concern for food safety and the environment. The truth is that these positions are defended by some representatives of the industry. Instead, it should be noted that, due to the polluting and predatory nature associated with the intensive use of natural resources, the industry must not fail to observe this principle and must reach reasonable interpretations, departing from conceptual extremism (Riechman and Tickner, 2002).

The essence of the precautionary principle is that society cannot wait, until all the answers are known, before adopting measures that protect the health of society and the environment from potential harm. Those who do not agree with the precautionary principle and adopt decisions based on technologies or activities that have not been properly tested or evaluated, place in the hands of society the responsibility of demonstrating that the technology or activity is unsafe or dangerous and how it has been appreciated Throughout history, it is society itself that pays for the effects of incorrect decisions, which, appreciated in good law, is unfair.

Analyzing the aforementioned, it can be seen that the concepts of the precautionary principle are placed before a scenario of conceptual confrontation. On the one hand, those who defend concepts based on ecological criteria aimed at reducing contemporary risks; and on the other, a vision focused on simple utilitarianism, which is committed to risk management and the benefits that this entails, as part of the process of growth and human well-being. Both positions from its extremes would be pernicious. It is necessary to find the equilibrium point from the legal systems and the results achieved in scientific knowledge.

For the legal solution aimed at finding the balance point between the two positions analyzed above, it is necessary to safeguard the conceptual pre-eminences of the precautionary principle of international environmental law. For this, the characteristics that distinguish said principle must be considered a priori.

When examining the existence of irreversible damage, it is not about assessing any type of environmental impact. It is about assessing the activities that lead to possible complex situations that represent a non-return

Pérez, A. V., Meza, D. R. C., Chávez, Ángel F. E., Macías, M. A. M., \& Cedeño, L. R. G. (2021). International environmental law and its le gal implication. International Journal of Life Sciences, 5(1), 1-13.

https://doi.org/10.29332/ijls.v5n1.1120 
to normal condition. These include the extinction of species, habitats or ecosystems, the interruption, alteration or modification of essential ecological processes. All of which can represent a potential risk to the balance of the environment.

It is recognized that there is no absolute scientific certainty, but there must be solid evidence validated by scientific information, which allows defining a hypothesis about a potential risk of a serious or irreversible nature. Any simplistic interpretation of the change in the environment as potentially harmful cannot be acceptable. The measures to mitigate the potential risk must be adopted prior to the evaluation of the impact in economic, social, environmental and health terms. Each of the elements must be evaluated by determining the costs and benefits that the application of restrictive measures entail, as well as those that would derive from inaction.

The measures must respond to the desired level of protection, since in some cases a total restriction may be the only possible variable. In other situations, less radical measures may be more appropriate, such as requiring further investigation or information from society regarding possible risks. The measures adopted must not be discriminatory and are required to be applied equally in similar situations. The use of trade barriers should be avoided under the pretext of protecting the environment. The measures must be provisional and variable. They require submission to scientific review and when it is concluded that the danger of harm is not serious or irreversible, the restriction must be lifted or modified as appropriate. Similarly, when a higher risk is indicated, more severe measures should be taken. The distinctive features of the precautionary principle are shown in Figure 1.

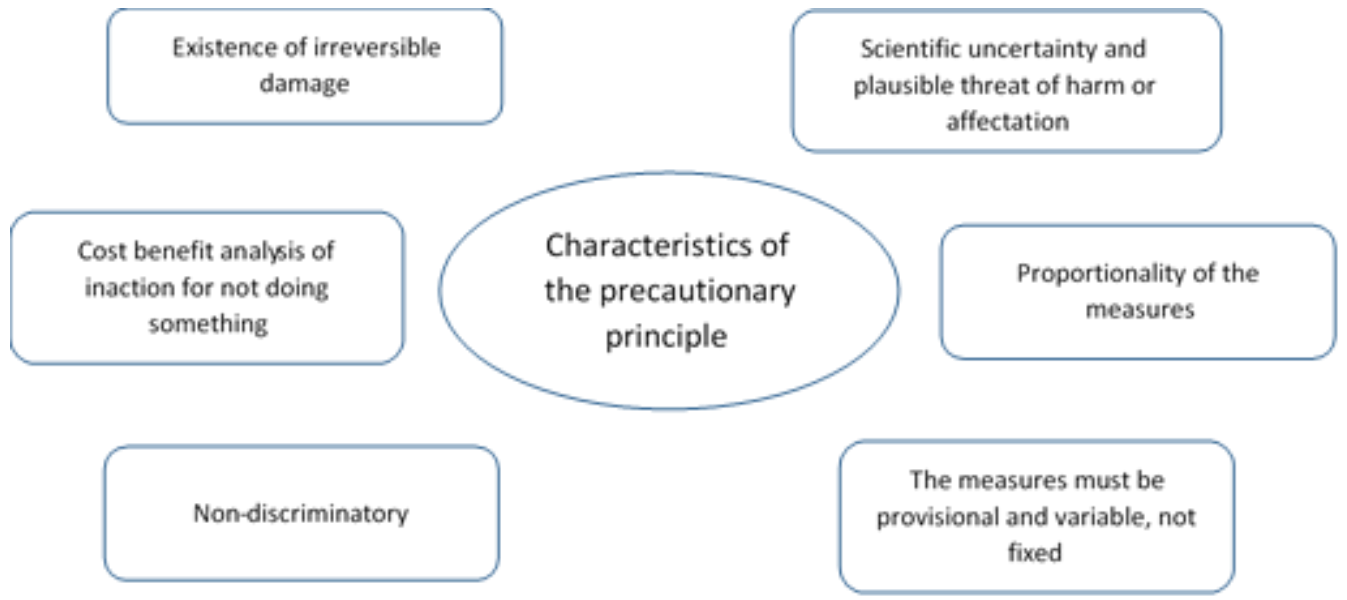

Figure 1. Distinctive characteristics of the precautionary principle Source: own elaboration from Andalusia 2002

The precautionary principle constitutes the essence for the normative policy of international environmental law. International regulations are based on the risk of environmental damage, rather than its consequences. This may entail a conflictual relationship between production relations and their economic results, with measures aimed at preserving the preservation of environmental conditions that guarantee sustainable development and, within them, regulation of the use of non-renewable natural resources.

\section{Normative considerations on environmental law at the international level}

In this way, at the international level, the legal approach to environmental problems began to gain greater importance, later leading to the conclusion of other international instruments on the environment such as: the Rio Declaration on Environment and Development (UN, 1992a), the United Nations Framework Convention on Climate Change (UN, 1992b), the Convention on Biological Diversity (UN, 1992c) and the Kyoto Protocol on Change Climate (UN, 1998).

Other international agreements signed for the protection of the environment are: Convention on International Trade in Endangered Species of Wild Fauna and Flora (UN, 1973); Cartagena Protocol on Biosafety (UN, 2003); International Convention for the Protection of New Varieties of Plants (UN, 1961); 
Cartagena Convention on the Protection and Development of the Marine Environment in the Caribbean Region (UN, 1983a); Protocol Relating to Cooperation to Combat Oil Spills in the Wider Caribbean Region (UN, 1983b); Vienna Convention for the Protection of the Ozone Layer (UN, 1985); Montreal Protocol on Substances that Deplete the Ozone Layer (UN, 1989); Basel Convention on the Transboundary Movement of Hazardous Wastes (UN, 1992d); Framework Convention on Climate Change (UN, 1992e); Rotterdam Convention on the Prior Informed Consent Procedure Applicable to Certain Pesticides and Chemicals in International Trade (UN, 2004a); Stockholm Convention on Persistent Organic Pollutants (UN, 2004b).

In 2000, 189 countries adopted the Millennium Declaration (UN, 2000) in New York, which strengthened the importance of sustainable development, recognizing the need for economic growth with a focus on the poor and respect for human rights. In 2002, 190 countries attended the United Nations World Summit on Sustainable Development in Johannesburg (ECLAC, 2002), focused on development and poverty eradication with a legal-economic focus on public-private partnerships. In 2012, the UN held the third Conference on Sustainable Development, known as Rio + 20, which convened 192 member states. The result was a nonbinding document called The Future We Want (UN, 2012), where States renewed their commitments to sustainable development and the promotion of a future that respects the rights of future generations.

The fight to face climate change gave way to the Paris Agreement (UN, 2015) and the signatory countries pledged to do everything possible to prevent the planet's average temperature from exceeding $2^{\circ} \mathrm{C}$, compared to pre-industrial levels. The relationship between human rights and climate change was recognized in its preamble. Having been ratified by almost every country in the world, it represents a potential instrument of international law.

A contemporary milestone of great relevance is Advisory Opinion 23 of 2017 on the environment and human rights of the Inter-American Court of Human Rights (Inter-American Court of Human Rights, 2017). It recognized for the first time the right to a healthy environment as fundamental for human existence, as well as the impacts of environmental degradation and climate change on human rights. In general, there are currently more than 250 international agreements of different types, aimed at environmental protection, which have influenced the adoption of constitutional regulatory frameworks in some countries. Examples of this are: the Constitution of Peru in 1993 (Democratic Constituent Congress, 1993), the Constitution of Colombia in 2002 (Sánchez, 2002), that of Chile in 2005 (Constituent Assembly, 2005), the Constitution of Ecuador in 2008 (Constituent Assembly, 2008) and the Political Constitution of the State of Bolivia (Constituent Assembly, 2009). But not everything is rosy, as some specialists argue that these rules are in contradiction with trade liberalization (WTO, 2016; Sarmiento, 2018). Which leads us to analyze the incidence of signed international legal instruments, compared to those who strongly defend trade liberalization.

\section{Non-binding nature of International Environmental Law}

Reflection on the non-binding nature of International Environmental Law is at the center of the permanent analysis of its sources (Shelton, 2003). The discussion of the subject has gained space in international law, beyond the criticisms made by some specialists (Klabbers, 1996) and is considered within the doctrine, as an element that has gained its place in the academic debate, on the problem related to the formation and adoption of international obligations and responsibilities (Gunther et al., 1988).

Non-binding norms of international environmental law are considered within the non-traditional sources of this type of law. But it is not precisely a concept that always leads to the same interpretation, in relation to other international instruments such as the Bruntland Report (UN, 1987) among other no less relevant documents. The pre-eminence of non-binding law in international environmental law is understood as a distinctive characteristic of this discipline, together with the need for binding law, which allows it to achieve adequate legal effectiveness.

The non-binding law is normatively manifested through two meanings: the first in the norm-making processes; in the second, when they appear in regulations that lack binding legal force, as in the cases of programs, resolutions, strategies, statements, conference proceedings, reports from expert groups, codes of conduct, among others (Valencia, 2008). The applicative dimension becomes evident when resolutions are published in the application of agreements that are not binding or in the presence of flexible and little consolidated institutions, where agile and flexible mechanisms must be used.

Pérez, A. V., Meza, D. R. C., Chávez, Ángel F. E., Macías, M. A. M., \& Cedeño, L. R. G. (2021). International environmental law and its legal implication. International Journal of Life Sciences, 5(1), 1-13.

https://doi.org/10.29332/ijls.v5n1.1120 
The significance of the non-binding rule in relation to international environmental law lies in the fact that it fosters the progressive development of new international and national law in general, as well as offers a relative harmonization of environmental law with the global socio-cultural standards that are currently manifested (Birnie and Boyle, 2002). It is important to note that international law as a whole is characterized by flexible, non-binding rules, which characterize it as a non-binding regulatory system. Especially on the environmental issue, it tends to shy away from the type of totalizing regulation and focuses on specific aspects of environmental problems. Therefore, it becomes a regulatory framework with a residual focus, by undertaking regulations that do not have an autonomous nature, as they are closely related to other sectors of international law (Valencia, 2008).

Non-binding regulation for international environmental law means a regulatory instrument that enables the projection of legal criteria and environmental principles that, without being mandatory, can establish a future path in the international, national and community regulatory system. That is why some specialists consider it as pre-law (Valencia, 2008). In the case of international environmental law, although a declaration does not impose legal obligations on states at the time of its adoption, it is clear that it acquires a binding meaning, when it is accepted and included as part of the constitutional rights of a state. A characteristic of non-binding regulation is that it takes effect through influence and not as an expression of positive law. It is a regulatory tool and is not based on the formal consequences of the violation for its effectiveness as a violation of the law, but on the general belief that soft law represents an officially accepted ethical and moral standard.

The non-binding character guides behavior and applies influence in a less tangible way and tends to disguise itself in the ostensible authority of the state and owes much of its effectiveness to that fact. It is typically defined as a non-legally binding law. However, it can have practical and indirect legal effects. Soft law does not create as strong an obligation to comply with its dictates as hard law, but it does carry its own unique advantages. Therefore, political scientists use the term soft law to describe the rules that guide behavior, but have not yet reached the formal status of hard or binding law. The following Table 1 shows the characteristic features that differentiate binding regulation from non-binding regulation.

Table 1

Differences between binding and non-binding

\begin{tabular}{l}
\hline Regulation Binding \\
\hline Respond directly to regulatory challenges \\
It establishes clearly defined obligations for the \\
entire society or subjects determined by law.
\end{tabular}

It invokes the political will of the ruling regime. It is approved by the legislative body and sanctioned by the President.

The processes of repeal and modification of laws can be more dynamic.

Laws are mandatory, regardless of the will of the people.

Laws are permanently subject to legal and constitutional control over their compliance.

Whoever violates the law is legally liable for his actions.

Treaties cannot respond to new challenges at the
regulatory level.

Because it is sometimes difficult to reach an agreement between the parties, they do not want to assume obligations that are not clearly defined.

Sometimes the consent of parties that do not have the capacity to sign a treaty under the rules of a convention is necessary.

Adopting or amending a treaty could take decades.

The consequences of non-compliance are more limited.

States can avoid the process of ratifying national treaties and perhaps escape democratic responsibility for the policy they agreed to. 
Environmental law in Latin America

The first notions of environmental protection in Latin America emerge from the consciousness of native peoples for the protection of the Pacha Mama. An ancestral idea that encompasses respect and adoration for nature, as an essential deity for the existence of all living beings on Earth.

Environmental law is a relatively recent specialized branch of law, which in its formation process has consolidated principles and concepts that make up the foundation of environmental institutionality, to ensure the constitutional guarantees of citizens (Ribadeneira, 2016). It arises from the need to legally protect natural resources. For this, the protection of the environment must be regulated, understanding the importance it has for the life of society.

Other authors point out that it is a branch of law that emerges from a combination of techniques, rules and legal instruments, to achieve the protection of all the elements that make up the natural and human environment, through a set of legal provisions that, due to their interdisciplinary nature They do not admit divided regimes and reciprocally condition and influence the scope of all existing legal and scientific branches (Jaquenod, 1991). In the constitutional law of Latin American countries in recent decades, environmental law has been developing with significant attention. The Political Constitution of the State of Bolivia (Constituent Assembly, 2009), establishes responsibility in the use of resources from nature and the rights inherent to it. It alludes to nature as Mother Earth, as part of the discourse related to the ancestral cultural values and traditions of indigenous peoples.

In the 1993 Constitution of Peru (Democratic Constituent Congress, 1993), a chapter is dedicated to the environmental issue, called the environment and natural resources. In the Peruvian constitutional text, it can be seen that the protection and promotion of natural resources is established as an obligation of the State and the enjoyment of a balanced and adequate environment for the development of life is constituted as a fundamental right. In the Constitution of 2005 (Constituent Assembly, 2005) in Chile, the right of people to live in an environment free of contamination is established. It can be seen that, in terms of the rights of nature, such a statement is very brief and does not proceed to promote actions to prevent damage to nature, until it affects the environment where people live. It is clear that the precautionary principle was far from the idea of the Chilean constitutional legislators in 2005.

In article 9 (Constituent Assembly, 2009) it establishes the essential purpose and function of the State, in addition to those established by the Constitution and the law. : Promote and guarantee the responsible and planned use of natural resources, and promote their industrialization, through the development and strengthening of the productive base in its different dimensions and levels, as well as the conservation of the environment, for the well-being of current and future generations ". In general, most Latin American constitutions address the environmental issue as a constitutional right. It is made clear that the exploitation and use of natural resources should not be indiscriminate, protecting the right to guarantee good living for current and future generations. On the other hand, it is recognized as a fundamental right to enjoy a healthy and ecologically balanced environment.

Thus, starting from Stockholm in 1972 with the celebration of the World Summit on Human Environment, the International Declaration on the Environment (UN, 1972) was proclaimed, which represented a call for the survival of humanity and the bases to consider the Earth as a suitable place for human life (Sarmiento, 2018). Since then, most of the countries undertook the establishment of policies and legal norms on environmental protection. What was a response to environmental problems caused by accelerated economic growth in industrialized countries.

\section{Environmental law in Ecuador}

As a background to the development of Ecuadorian environmental law, it can be observed that, on January 30, 1975, the Country signed the Washington Convention (UN, 1940) for the Protection of Flora, Fauna and Beauties Scenic Naturals of the Countries of America and during the second half of the 20th century, considerable progress was achieved in the field of environmental law at the constitutional level.

In the Constitution of Ecuador of 1979 (Constituent Assembly, 1979) the right to live in an environment free of contamination was established. The duty of the state was endorsed to ensure that this right is not

Pérez, A. V., Meza, D. R. C., Chávez, Ángel F. E., Macías, M. A. M., \& Cedeño, L. R. G. (2021). International environmental law and its legal implication. International Journal of Life Sciences, 5(1), 1-13.

https://doi.org/10.29332/ijls.v5n1.1120 
affected and enshrined the protection of nature, referring to a specific law with the aim of establishing restrictions on rights or freedoms aimed at protecting the environment.

In the Political Constitution of 1998 (National Constituent Assembly, 1998), the rights related to the environment and natural resources were expanded. A specific section was dedicated to environmental protection. The infractions, administrative, civil and criminal sanctions for actions or omissions against the norms of protection of the environment were established. environment. The entry of nuclear waste and toxic waste into the national territory was prohibited, and the ownership of the action was granted to any natural or legal person, in the interest of materializing the protection of the environment.

This constitution grants special protection to the provinces of the Amazon region, to protect biodiversity in the interest of sustainable development. The defense of the natural and cultural heritage of the country and the protection of the environment were established as a primary duty of the State. For this, the right to live in a healthy, ecologically balanced and pollution-free environment is recognized, as well as the state power to expropriate, reserve and control the territory, in order to exercise the conservation of the environment, guaranteeing state sovereignty over non-renewable natural resources, biological diversity, natural reserves, protected areas and national parks (Vázquez, 2018).

The Constitution approved in 2008 (Constituent Assembly, 2008), is distinguished by innovative changes related to environmental protection. Nature is granted legal personality, and it becomes in fact a subject of law and therefore as the holder of the same rights that had only been recognized to human beings and legal persons. Una de las cuestiones que más se destaca desde el punto de vista jurídico, está relacionada con la modificación de la concepción tradicional, al considerar a la naturaleza como sujeto de derecho. El texto constitucional incursiona en la transformación conceptual de varios temas relacionados con el régimen de desarrollo y la inclusión del buen vivir o sumak kawsay y los eleva constitucionalmente a factores orientadores de la vida (Bedón, 2017).

The 1998 Constitution opens the possibility for the materialization of novel environmental relations, which mark a before and after in the environmental constitutional regulation. It constitutes the culmination of a process in this area, of constitutionalization of the environment, which had been developing in Latin America. The Constitution of Ecuador of 2008 together with that of Venezuela and Bolivia, are endorsed in very similar socio-political and economic spaces, which demonstrated new ways of governing and bet on a new world of relationships between man and nature (Macías, 2009).

International environmental law is a relatively new branch of legal science, although antecedents are known dating from the year 1868, when a lawsuit was filed with the Ministry of Foreign Affairs of the AustroHungarian Empire, by a group of farmers concerned about the hunting of insectivorous birds, carried out by the highly developed plumage industry in the wake of Victorian fashion, which imposed feathers for ladies' hats. The lawsuit asked Emperor Francisco José to sign an international treaty to protect beneficial birds in agriculture (Menéndez, 2011). Given the nature of international environmental law, it can be seen that it is based on a group of norms and regulations where the non-binding nature of the established regulation prevails, which despite this is conducive to the establishment of commitments and agreements signed by the countries. , aimed at achieving sustainability through the preservation of natural resources, the care of biological diversity and the reduction of environmental pollution through the proper management of natural resources (Riechman and Tickner, 2002).

Environmental law focuses on the production, exploitation and use of natural resources, linked to the concepts of sustainable development. The central axis of this right turns in the sense of environmental conservation, issues that must be treated as a whole. One should not be prioritized over the other, since economic issues and environmental conservation constitute a whole in the interest of guaranteeing sustainable development, considering it as the improvement of the quality of human life in harmony with the capacity of the ecosystem (Narváez, 2004).

The legal-environmental problem is an outstanding issue as it has a direct impact on the development of society, which is why it experiences a transcendence for the economic, social and environmental development of the Country. That is why the prevailing need arises to effectively protect the protection of the environment, trying to avoid the degradation of the natural environment to the point that it can disrupt individual and collective rights, which implies that the state must intervene to guarantee them. In the Latin American constitutions approved in the last 30 years, one can see the inclusion of principles and rules that regulate environmental protection and defend the principles of sustainable development. The regulation of the 
relationships between man, the environment and nature is introduced. For this, the right to a healthy environment, ecologically balanced, free of contamination, is recognized as an expression of the fundamental rights of people. Which shows the importance of environmental law within the development of modern society.

The Ecuadorian constitution fosters the generation of a new paradigm, not always well interpreted by some legal specialists who carry out a technical interpretation from the conceptions of traditional constitutionalism, where nature was not considered endowed with legal personality to guarantee good living and sustainability for future generations.

\section{Conclusion}

It has been possible to verify the influence exerted by international law on the new Latin American constitutionalism, with the aim of ensuring the sustainability of future generations and the rights of human beings to live in a healthy environment. The comparative analysis of the Ecuadorian constitutions approved in the years 1979, 1998 and 2008, would define that during thirty years important changes took place in the constitutional regulatory matter on the environmental issue, which detects a reflection of the influence of international environmental law, in interest in the constitutionalization of issues associated with the environment, as a binding legal solution for environmental regulations in the interior of the country.

In the 2008 Constitution, the legislators managed to reflect a broad regulation of the environmental concept, which includes a vision aimed at guaranteeing the rights of good living, in harmony and respect for the rights of nature. The 2008 Constitution led to the opening of a paradigm in the environmental concept, overcoming the protectionist simplification of the environment as an object of law, to establish it as a subject of rights, which means the opening of a new perspective for jurisprudence, which does not It only seeks to protect nature as an object of law, but considers nature as a subject of rights, which go beyond its mere protection to include various dimensions, such as: comprehensive protection, comprehensive reparation, sustainable development, interpretation of pro natura rights, sustainable and transversal environmental policies. In the man-nature relationship, the 2008 Constitution defined the scope of the Good Living doctrine in its different rights, among which the right to a healthy, ecologically balanced environment, free from any contamination, can be pointed out, under the vision of the respect for biological diversity and protected areas, ensuring sustainable ecological policies, inspired by the use of endogenous renewable resources in the territories.

International environmental law is made up of different norms that regulate the relations between society and the environment in a framework of coexistence, cooperation and interdependence, which may or may not be institutionalized and whose objective is the international protection of nature. Due to the international involvement of environmental law, most of the legal body of this branch of law is characterized by nonbinding norms, which do not imply a mandatory relationship for compliance; but they constitute an unquestionable source for the legal system in environmental matters, at the level of the countries that make up the United Nations community. Some of the regulations are materialized through international agreements and conventions, which, once signed, constitute an ethical and moral requirement for compliance.

Pérez, A. V., Meza, D. R. C., Chávez, Ángel F. E., Macías, M. A. M., \& Cedeño, L. R. G. (2021). International environmental law and its legal implication. International Journal of Life Sciences, 5(1), 1-13. 


\section{References}

Andaluz, C. (2002). Derecho Ambiental: el principio precautorio. Foro Jurídico, (01). Pontificia Universidad del Perú.

P.

143-147. <http://revistas.pucp.edu.pe/index.php/forojuridico/article/view/18274/18519>

Artigas, C. (2001). El principio precautorio en el derecho y la política internacional. CEPAL Serie recursos naturales e infraestructura $\mathrm{N}^{\circ}$ 22. 2001. < https://digitallibrary.un.org/record/441565? ln=es>

Asamblea Constituyente. (2005). Constitución Política de la República de Chile. Decreto Supremo No 100 de 17 de septiembre de 2005, Santiago de Chile. <http://www.subdere.gov.cl/sites/default/files/documentos/articles-83868_archivo_fuente.pdf>

Asamblea Constituyente. (2008). Constitución de la República del Ecuador 2008. Registro Oficial 449 de 20oct-2008. Última modificación: 13-jul-2011. <https://www.oas.org/juridico/pdfs/mesicic4_ecu_const.pdf>

Asamblea Constituyente. (2009). Constitución Política del Estado (CPE). Bolivia (7-febrero-2009). $<$ https://www.oas.org/dil/esp/constitucion_bolivia.pdf>

Asamblea Nacional Constituyente. (1979). Constitución Política del Ecuador. Registro Oficial 800 de 27 de marzo de 1979. <https://www.cancilleria.gob.ec/wp-content/uploads/2013/06/constitucion_1978.pdf>

Asamblea Nacional Constituyente. (1998). Constitución Política del Ecuador. RO/ 1 de 11 de agosto de 1998. < https://www.wipo.int/edocs/lexdocs/laws/es/ec/ec016es.pdf>

Baxter, R. (1980). International law in "her infinite variety", International and Comparative Law Quarterly, Vol. 29, October, 1980, pp. 549-566

Bedón, R. (2017). Aplicación de los Derechos de la Naturaleza en Ecuador. Veredas do Direito: Direito Ambiental e Desenvolvimento Sustentável. Belo Horizonte. Vol. 14. Número 28. 2017. Pág. 15.

Birnie, P., y Boyle, A. (2002). International Law \& The environment. Second Edition. University Press Oxford. Oxford 2002, págs $24-27$.

CEPAL. (2002). Cumbre Mundial sobre el Desarrollo Sostenible. Comisión Económica para América Latina y el Caribe. Documento en línea. Consultado el 11 de diciembre de 2020. <https://www.cepal.org/es/eventos/cumbre-mundial-desarrollo-sostenible>

Congreso Constituyente Democrático. (1993). Constitución Política del Perú. <https://pdba.georgetown.edu/Parties/Peru/Leyes/constitucion.pdf>

Cooter, R. D. (1994). Structural adjudication and the new law merchant: a model of decentralized law. International Review of Law and Economics, 14(2), 215-231. https://doi.org/10.1016/01448188(94)90020-5

Corte Interamericana de Derechos Humanos. (2017). Opinión Consultiva OC-23/17. Documento en línea. Consultado el 11 de marzo de 2021. <https://www.corteidh.or.cr/docs/opiniones/seriea_23_esp.pdf>

Covaci, A., Harrad, S., Abdallah, M. A. E., Ali, N., Law, R. J., Herzke, D., \& de Wit, C. A. (2011). Novel brominated flame retardants: a review of their analysis, environmental fate and behaviour. Environment international, 37(2), 532-556. https://doi.org/10.1016/j.envint.2010.11.007

Giles, R. (2003). La amenaza contra la capa de ozono y el cambio climático: respuesta jurídico-internacional. Artes Gráficas Bonanza, SL Universidad de Huelva, España, 2003. <http://rabida.uhu.es/dspace/handle/10272/15733>

Gunther, F. Handl, W. Reisman, M. Simma, B. Dupuy, P., y Chinkin, C. (1988). Actas de la reunión anual de la Sociedad Estadounidense de Derecho Internacional. Cambridge University Press. Vol. 82 (20-23 de abril de 1988), págs.371-395. <https://www.jstor.org/stable/25658434?seq=1>

Hernández, R., Fernández, C., y Baptista, M. (2010). Metodología de la Investigación 5ta Edición. México: McGRAW-HILL / Interamericana Editores, SA DE CV

Hofman, J., \& Sutherland, A. (2018). Evaluación de intervenciones que previenen o contrarrestan el extremismo violento (Vol. 1). Santa Mónica, California: RAND Corporation. <https://Downloads/libro\%20de\%20Desk\%20based.pdf>

Jaquenod, S. (1991). El Derecho Ambiental y sus principios rectores (2da Ed.) Madrid: Dyckinson. Pág. 89.

Klabbers, J. (1996). The redundancy of soft law", Nordic Journal of International Law 65, 1996, pp. 167-182.

Lagos, E. (2005). Algunas tendencias del derecho internacional a principios del siglo XXI", Anuario Mexicano de Derecho Internacional, vol. V, 2005, pp. 309-335. 
Law, B. E., Falge, E., Gu, L. V., Baldocchi, D. D., Bakwin, P., Berbigier, P., ... \& Wofsy, S. (2002). Environmental controls over carbon dioxide and water vapor exchange of terrestrial vegetation. Agricultural and Forest Meteorology, 113(1-4), 97-120. https://doi.org/10.1016/S0168-1923(02)00104-1

Macías, L. (2009). El constitucionalismo ambiental en la nueva Constitución de Ecuador. Un reto a la tradición constitucional". Iuris Dictio. Revista de Derecho. Vol. 8, Número 12. 2009. Pág. 21.

Menéndez, A. (2011). La Constitución Nacional y el medio ambiente (el art. 41 de la CN). Editorial: Ediciones Jurídicas Cuyo, Mendoza. <https://www.iberlibro.com/servlet/BookDetailsPL?bi=16032880948\&cm_sp=rec-_-pd_hw_o_1-_bdp\&reftag=pd_hw_o_1>

Millard, S. G., Law, D., Bungey, J. H., \& Cairns, J. (2001). Environmental influences on linear polarisation corrosion rate measurement in reinforced concrete. $N d t$ \& E International, 34(6), 409-417. https://doi.org/10.1016/S0963-8695(01)00008-1

Narváez, I. (2004). Derecho Ambiental y temas de Sociología Ambiental" (conflictos socio ambientales en el sector extractivo: enfoque político). Quito: Cevallos. 2004. Pág. 297.

OMC. (1996). Venezuela y Brasil contra los Estados Unidos: gasolina. Casos 2 y 4 de la OMC. Organización Mundial del Comercio.<https://www.wto.org/spanish/tratop_s/envir_s/edis07_s.htm>

ONU. (1940). Convención para la Protección de la Flora, de la Fauna y de las Bellezas escénicas Naturales de los Países de América. Asamblea General de la Organización de las Naciones Unidas. <https://www.fws.gov/international/pdf/convention-text-western-hemisphere-convention-spanish.pdf>

ONU. (1946). Convenio Internacional para la reglamentación de la Caza de la Ballena. Asamblea General de la Organización de las Naciones Unidas. Firmado en Washington el 2 de diciembre de 1946. <http://apw.cancilleria.gov.co/tratados/AdjuntosTratados/606a0_CAZABALLENAS-1946.PDF>

ONU. (1961). Convenio Internacional para la Protección de las Obtenciones Vegetales. Revisado en Ginebra el 10 de noviembre de 1972, el 23 de octubre de 1978 y el 19 de marzo de 1991. <https://www.wipo.int/edocs/lexdocs/treaties/es/upov/trt_upov_3.pdf>

ONU. (1972). Informe de la Conferencia de las Naciones Unidas sobre el Medio Humano-Estocolmo, 5 a 16 de junio de 1972 (A/CONF.48/14/REV.1). <https://www.dipublico.org/conferencias-diplomaticas-nacionesunidas/conferencia-de-las-naciones-unidas-sobre-el-medio-humano-estocolmo-5-a-16-de-junio-de$1972 />$

ONU. (1973). Convención sobre el Comercio Internacional de Especies Amenazadas de Fauna y Flora Silvestres. Enmendada en Bonn, el 22 de junio de 1979 y en Gaborone, el 30 de abril de 1983. $<$ https://cites.org/sites/default/files/esp/disc/CITES-Convention-SP.pdf>

ONU. (1983a). Convenio de Cartagena sobre la Protección y el Desarrollo del Medio Marino en la Región del Caribe. <https://aplicaciones.sre.gob.mx/tratados/ARCHIVOS/MEDIO\%20MARINO.pdf>

ONU. (1983b). Protocolo relativo a la Cooperación para Combatir los Derrames de Hidrocarburos en la Región del Gran Caribe. <http://apw.cancilleria.gov.co/tratados/AdjuntosTratados/9f152_GRANCARIBE1983\%20HIDRO.PDF>

ONU. (1985). Convenio de Viena para la Protección de la Capa de Ozono. Organización de las Naciones Unidas. <https://aplicaciones.sre.gob.mx/tratados/archivos/convenio\%20capa\%20de\%20ozono.pdf>

ONU. (1987). Informe de la Comisión Mundial sobre el Medio Ambiente y el Desarrollo. Asamblea General de la Organización de las Unidas. <http://www.ecominga.uqam.ca/PDF/BIBLIOGRAPHIE/GUIDE_LECTURE_1/CMMAD-Informe-ComisionBrundtland-sobre-Medio-Ambiente-Desarrollo.pdf>

ONU. (1989). Protocolo de Montreal relativo a las Sustancias que Agotan la Capa de Ozono. Decisión 88/540/CEE del Consejo. <https://eur-lex.europa.eu/legalcontent/ES/TXT/HTML/?uri=LEGISSUM:4413653>

ONU. (1992a). Declaración de Río sobre el Medio Ambiente y el Desarrollo. Conferencia de las Naciones Unidas sobre el Medio Ambiente y el Desarrollo. <https://www.un.org/spanish/esa/sustdev/documents/declaracionrio.htm>

ONU. (1992b). Convención Marco de las Naciones Unidas sobre el Cambio Climático. fccc/informal/84. ge.0562301 (s) 220705 220705. <https://unfccc.int/resource/docs/convkp/convsp.pdf>

Pérez, A. V., Meza, D. R. C., Chávez, Ángel F. E., Macías, M. A. M., \& Cedeño, L. R. G. (2021). International environmental law and its legal implication. International Journal of Life Sciences, 5(1), 1-13. 
ONU. (1992c). Convenio de las Naciones Unidas sobre Diversidad Biológica. Registro Oficial 647 de 06 -mar.$1995 . \quad$ Última modificación: 16-mar.-1993. <https://www.ambiente.gob.ec/wpcontent/uploads/downloads/2017/12/CONVENIO-SOBRE-DIVERSIDAD-BIOLOGICA.pdf>

ONU. (1992d). Convenio de Basilea sobre el Movimiento Transfronterizo de Desechos Peligrosos. Programa de las Naciones Unidas para el Medio Ambiente (PNUMA). <https://www.basel.int/Portals/4/Basel\%20Convention/docs/text/BaselConventionText-s.pdf>

ONU. (1992e). Convenio Marco del Cambio Climático. FCCC/INFORMAL/84. GE.05-62301 (S) 220705. <https://unfccc.int/resource/docs/convkp/convsp.pdf>

ONU. (1998). Protocolo de Kyoto de la Convención Marco de las Naciones Unidas sobre el Cambio Climático. $\begin{array}{llll}\text { FCCC/INFORMAL/83. } & \text { GE.05-61702 } & \text { (S) } & 130605\end{array}$ <https://unfccc.int/resource/docs/convkp/kpspan.pdf>

ONU. (2000). Declaración del Mileno. Resolución aprobada por la Asamblea General. Quincuagésimo quinto período de sesiones. Tema 60 b) del programa. Documento en línea. Consultado el 11 de diciembre de 2020. <https://www.un.org/spanish/milenio/ares552.pdf>

ONU. (2003). Protocolo de Cartagena sobre Seguridad de la Biotecnología. Convenio 1 Registro Oficial 145 de 12-ago.-2003. Ministerio de Relaciones Exteriores. <https://www.ambiente.gob.ec/wpcontent/uploads/downloads/2018/05/Protocolo-Cartagena-Seguridad-de-la-Biotecnologia.pdf>

ONU. (2004a). Convenio de Rotterdam sobre el Procedimiento de Consentimiento Fundamentado Previo Aplicable a Ciertos Plaguicidas y Productos Químicos en el Comercio Internacional. <https://Downloads/UNEP-FAO-RC-CONVTEXT-2015.Spanish.pdf>

ONU. (2004b). Convenio de Estocolmo sobre los Contaminantes Orgánicos Persistentes (POPS). Enmendado en 2009. Programa de las Naciones Unidas para el Medio Ambiente (PNUMA). <https://www.wipo.int/edocs/lexdocs/treaties/es/unep-pop/trt_unep_pop_2.pdf>

ONU. (2012). El futuro que queremos. Documento final de la Conferencia de las Naciones Unidas sobre el Desarrollo Sostenible. Río de Janeiro, Brasil, 20-22 junio 2012. Asamblea General de la Organización de las Naciones Unidas. <https://sustainabledevelopment.un.org/content/documents/764Future-We-WantSPANISH-for-Web.pdf>

ONU. (2015). Acuerdo de París. Asamblea General de la Organización de las Naciones Unidas. <https://unfccc.int/sites/default/files/spanish_paris_agreement.pdf>

Pastor, J. (2002). Curso de derecho internacional público y organizaciones internacionales, 8a. ed., Tecnos, Madrid, 2002, pp. 156-157

Ribadeneira, M. (2016). ¿Derecho ambiental ecuatoriano, quo vadis? Madrid: Ius Humani. Revista de Derecho. Volumen 5. 2016. Pág. 190.

Riechman, J., y Tickner, J. (2002). El principio de precaución. Colección Icaraia Más Madera, , Barcelona, España. $\quad$ Pgs. $160 . \quad<$ https://www.amazon.com/-/es/Jorge-RiechmannFern\%C3\%A1ndez/dp/8474265819>

Sánchez, G. (2002). Desarrollo y medio ambiente: una mirada a Colombia. Revista Economía y Desarrollo, 2002. P. 92. <http://uac1.fuac.edu.co/revista/M/seis.pdf>

Sarmiento, J. (2018). Cuando el comercio internacional se encontró con el medio ambiente, entre el soft law y la prohibición a las barreras al comercio. Anuario Colombiano de Derecho Internacional, vol. 11, 2018. <https://doi.org/10.12804/revistas.urosario.edu.co/acdi/a.6542>

Scanlon, N. L. (2007). An analysis and assessment of environmental operating practices in hotel and resort properties. International Journal of Hospitality Management, 26(3), 711-723. https://doi.org/10.1016/j.ijhm.2006.07.003

Sesma, B. Díaz, I., y Müller, L. (2004). Segundas Jornadas sobre globalización y derechos humanos: bioética y biotecnología. Jornadas sobre Globalización y Derechos Humanos. UNAM, México, $2004 .<$ http://ru.juridicas.unam.mx/xmlui/handle/123456789/10418>

Shelton, D. (2003). International Law add relative normativity en Evans, Malcolm (ed.), International Law, Oxford, University Press, 2003.

Thürer, D. (2000). Soft Law", en R. Bernhardt (ed.), Encyclopedia of Public International Law, 2000, pp. 454 460

Valencia, F. (2008). Soft law y derecho internacional ambiental algunas aplicaciones nacionales. Revista Boliviana de Derecho, (5),65-84. <https://www.redalyc.org/articulo.oa?id=427539905005> 
Vastag, G., Kerekes, S., \& Rondinelli, D. A. (1996). Evaluation of corporate environmental management approaches: A framework and application. International Journal of Production Economics, 43(2-3), 193211. https://doi.org/10.1016/0925-5273(96)00040-0

Vázquez, E. (2018). Los derechos de la naturaleza, sus fines teleológicos y el buen vivir. Ambato: Uniandes. 2018. Pág. 14.

\section{Biography of Author}

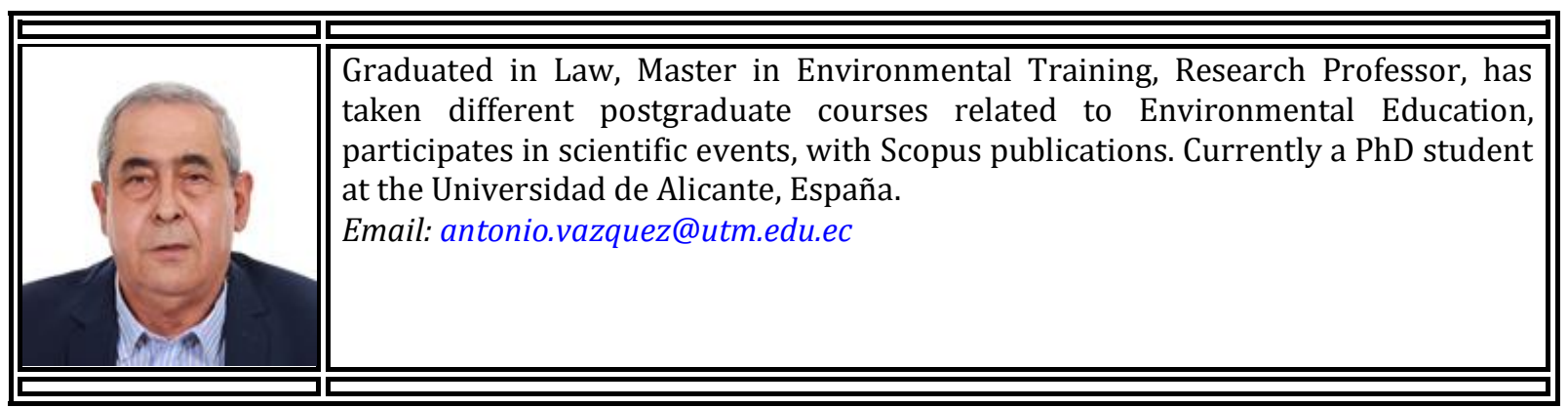

Pérez, A. V., Meza, D. R. C., Chávez, Ángel F. E., Macías, M. A. M., \& Cedeño, L. R. G. (2021). International environmental law and its legal implication. International Journal of Life Sciences, 5(1), 1-13. https://doi.org/10.29332/ijls.v5n1.1120 